\title{
GABAA Receptor but Not Muscarinic Receptor Density Was Decreased in the Brain of Patients with Parkinson's Disease
}

\author{
Naoki NISHINO ${ }^{1}$, Hiroshi FUJIWARA', \\ Sadako A. NOGUCHI-KUNO ${ }^{2}$ and Chikako TANAKA ${ }^{1, *}$ \\ 1 Department of Pharmacology, Kobe University School of Medicine, \\ Kusunoki-cho, Chuo-ku, Kobe 650, Japan \\ ${ }^{2}$ Department of Neurology, Utano National Hospital, Narutaki Ondoyama-cho, \\ Ukyo-ku. Kyoto 616, Japan
}

Accepted July 21, 1988

\begin{abstract}
The activity of glutamic acid decarboxylase (GAD) and choline acetyltransferase (ChAT) as presynaptic markers of $\gamma$-aminobutyric acid (GABA) - and acetylcholine (ACh)-containing neurons, and the binding of $\left[{ }^{3} \mathrm{H}\right]$ muscimol and $\left[{ }^{3} \mathrm{H}\right]$ quinuclidinyl benzilate $\left(\left[{ }^{3} \mathrm{H}\right] \mathrm{ONB}\right)$ as postsynaptic ones were measured in autopsied samples of the caudate nucleus, putamen, pallidum, substantia nigra and the cerebral cortex from L-dopa-treated patients with Stage $V$ (terminally bedridden) patients with Parkinson's Disease (PD). In PD, GAD activities were significantly reduced in the caudate nucleus and substantia nigra relative to normal controls, but were normal when the values from protracted terminal illness (PTI) cases were used as the controls. ChAT activities were reduced in all regions studied. These reductions in GAD and ChAT activities were not accompanied by a concomitant increase in the density of $\mathrm{GABA}_{\boldsymbol{A}}$ or muscarinic receptors. GABA $\mathrm{A}_{\mathbf{A}}$ receptor densities were significantly decreased in both the cortical and subcortical brain regions, while muscarinic receptor densities remained unchanged. We suggest that the decreased density of $\mathrm{GABA}_{A}$ receptor in PD brains reflects degeneration of neurons on which the receptor is localized, i.e., degeneration of ascending monoaminergic neurons including nigral dopamine (DA) neurons.
\end{abstract}

No doubt the major neurochemical defect in Parkinson's Disease (PD) is loss of dopamine (DA), its main metabolite homovanillic acid, and its synthesizing enzymes tyrosine hydroxylase and DOPA decarboxylase in the striatum (caudate nucleus, putamen), substantia nigra and the pallidum. These changes are attributable to the degeneration of the melanin-containing neurons in the substantia nigra zona compacta (SNC) which give rise to the nigrostriatal and nigropallidal DA pathway innervating the basal ganglia. In addition to these changes, there is growing evidence for the alterations of other putative neurotransmitter and neuromodulator systems. Among these, the alterations related to the GABA and $\mathrm{ACh}$ con-

\footnotetext{
* To whom reprint requests should be addressed.
}

taining neurons of the basal ganglia are of particular interest because of their possible functional relationship with the DA neurons. In PD brain, GAD and ChAT activity have been shown to decrease in several regions including the nigra $(1-3)$ and GABA concentration has been found to increase in the striatum (4). $\mathrm{Na}^{2+}$-independent $\left[{ }^{3} \mathrm{H}\right] \mathrm{GABA}$ binding were reported to be lost in the PD nigra $(5,6)$, while muscarinic receptor labeled by $\left[{ }^{3} \mathrm{H}\right] \mathrm{ONB}$ increased in the frontal cortex (7). Most studies have measured these receptor markers for GABA and $\mathrm{ACh}$ independently and the clinical stage of their patients at autopsy has not been given. thereby making interpretation of the data sets complicated. Moreover, new radioligands such as $\left[{ }^{3} \mathrm{H}\right]$ muscimol $(8)$ and $\left[{ }^{3} \mathrm{H}\right]$ baclofen (9), and $\left[{ }^{3} \mathrm{H}\right]$ pirenzepine (10) were in- 
troduced in the recent past to discriminate subpopulations of GABA and muscarinic receptors. Yet there has been no study done using these ligands on postmortem brains of PD. Therefore, we simultaneously measured the activities of GAD and ChAT, and the bindings of $\left[{ }^{3} \mathrm{H}\right]$ muscimol, $\left[{ }^{3} \mathrm{H}\right]$ QNB and $\left[{ }^{3} \mathrm{H}\right]$ pirenzepine on autopsied brain samples from patients with Stage $V$ (terminally bedridden) PD.

\section{Materials and Methods}

Tissue collection: Autopsied brain samples were obtained from eight patients $(5$ men, 3 women; age $70 \pm 2$ years, range 59-79 years) with idiopathic Parkinson's Disease (PD). All patients were terminally bedridden (Clinical Stage $V$ according to Hoehn and Yahr (11)) prior to death. The mean duration of illness was 10 years. The averaged bedridden period was 11 months. All were receiving $L$-dopa with or without peripheral decarboxylase inhibitors, the daily L-dopa dose varying from 150 to $1500 \mathrm{mg}$ per day for $2-10$ years. A slight increase in L-dopa dosage frequently caused dyskinesias in all cases. In addition to L-dopa, three patients were treated with anticholinergics (trihexyphenidyl and benztropine) and one with amantadine. In four cases, however, no antiparkinsonian drugs had been given for a month or more before death. The major clinical features of our cases are shown in Table 1. Fourteen control brains ( 9 men, 5 women; age $64 \pm 3$ years, range $42-84$ years) were obtained through the Departments of Legal Medicine, Pathology and Anatomy. Kobe University School of Medicine and had no known neuropsychiatric disorders. Their causes of death were considered under two major categories of agonal status: sudden death (SD) cases where death occurred unexpectedly in those who had previously been well or protracted illness (PTI) cases where death followed after being confined to a hospital for at least one month.

Tissue dissection: All dissections were performed on an ice-cold plate. Areas excised for this study were the motor cortex (Brodmann area 4), premotor cortex (Brodmann area 6), prefrontal cortex (Brodmann area 9). caudate nucleus, putamen, globus pallidus and substantia nigra. For ChAT assay, the thalamus was used in place of the substantia nigra because only a very limited amount of nigral tissue was available. The tissue blocks excised were kept at $-75^{\circ} \mathrm{C}$ until assayed. The mean time interval between death and autopsy were $7 \mathrm{hr}$ for the controls and $5 \mathrm{hr}$ for the parkinsonians; mean storage time in freezer were 10 months for controls and 11 months for parkinsonians.

Preparation of tissue: For enzyme assays, tissue samples were homogenized either in ice-cold distilled water (GAD assay: $5.0 \%$ $\mathrm{W} / \mathrm{v}$ for cerebral cortices and $2.0 \% \mathrm{w} / \mathrm{v}$ for subcortical areas) or in $10 \mathrm{mM}$ ethylenediaminetetraacetic acid (EDTA), $\mathrm{pH} 7.4$, containing $0.5 \% \mathrm{v} / \mathrm{v}$ Triton $\mathrm{X}-100$ (ChAT assav: $5.0 \% \mathrm{~W} / \mathrm{v}$ for cerebral cortices and $2.5 \% \mathrm{w} / \mathrm{v}$ for subcortical areas), using a Tefion-glass homogenizer (1000 rpm/10 strokes).

Crude membrane preparations: Membranes were prepared by homogenizing the tissue in a polytron homogenizer (Kinematica PT-10: setting $7,20 \mathrm{sec}$ ) containing $20 \mathrm{vol}$. of ice-

Table 1. Clinical details of parkinsonians

\begin{tabular}{llcclc}
\hline Age/Sex & $\begin{array}{c}\text { Duration of } \\
\text { illness }(\mathrm{yr})\end{array}$ & $\begin{array}{c}\text { Bed-ridden } \\
\text { period (mo) }\end{array}$ & Medication & $\begin{array}{c}\text { Drug free } \\
\text { interval (mo) }\end{array}$ \\
\hline P1 & $59 / \mathrm{M}$ & 5 & 3 & L-Dopa+carbidopa & 1 \\
P2 & $67 / \mathrm{M}$ & 11 & 21 & $\begin{array}{l}\text { L-Dopa+benserazide, } \\
\text { trihexyphenidyl, amantadine }\end{array}$ & 2 \\
P3 & $67 / F$ & 15 & 3 & $\begin{array}{l}\text { L-Dopa+carbidopa, } \\
\text { benztropine }\end{array}$ & 3 \\
P8 & $78 / \mathrm{F}$ & 2 & 7 & L-Dopa+carbidopa & 3 \\
P4 & $68 / \mathrm{F}$ & 13 & 7 & L-Dopa+carbidopa & 0 \\
P5 & $75 / \mathrm{M}$ & 15 & 23 & L-Dopa, benztropine & 0 \\
P6 & $76 / \mathrm{M}$ & 7 & 4 & L-Dopa+benserazide & 0 \\
P7 & $76 / \mathrm{M}$ & 12 & 20 & L-Dopa+carbidopa & 0 \\
\hline
\end{tabular}


cold $50 \mathrm{mM}$ Tris- $\mathrm{HCl}$ buffer, $\mathrm{pH} 7.4$ (Tris buffer). These homogenates were then centrifuged at $50,000 \times g$ for $10 \mathrm{~min}$, and the pellets obtained were taken through 3 -more washing steps as above, and the washed membranes were resuspended in 20 vol. (original wet weight) of Tris buffer. For experiments in which the tissue was Tritontreated, Triton X-100 to a final concentration of $0.05 \% \mathrm{v} / \mathrm{v}$ was added to the initial resuspension which was then incubated at $25^{\circ} \mathrm{C}$ for $30 \mathrm{~min}$. The Triton-treated tissue was then washed 3 times in Tris buffer as above for the regular tissue preparation.

Enzyme assays: GAD activity was determined by the fluorescence of the NADPH produced using the method of Okada et al. (12). ChAT activity was measured by the method described by Fonnum (13), using $\left[{ }^{14} \mathrm{C}\right]$ acetyl-Coenzyme $A$ as a substrate. Enzyme activity is expressed as $\mu \mathrm{mol} / \mathrm{hr} / 100$ mg protein.

Binding assays: For $\mathrm{GABA}_{A}$ receptor binding, the tritonized membranes (0.5-0.7 $\mathrm{mg}$ protein per assay) were incubated in 0.6 $\mathrm{ml}$ of Tris buffer for 30 min at $0{ }^{\circ} \mathrm{C}$ with $\left[{ }^{3} \mathrm{H}\right]$ muscimol (final concentrations: 2.5-160 nM) in the presence (non-specific binding) and absence (total binding) of $100 \mu \mathrm{M}$ unlabeled GABA. For muscarinic receptor binding, the washed membranes $(0.5-0.7 \mathrm{mg}$ protein per assay) were incubated in $0.6 \mathrm{ml}$ of Tris buffer for $60 \mathrm{~min}$ at $25^{\circ} \mathrm{C}$ with $\left[{ }^{3} \mathrm{H}\right] \mathrm{QNB}(1 \mathrm{nM})$ or with $\left[{ }^{3} \mathrm{H}\right]$ pirenzepine $(0.06-32 \mathrm{nM})$ in the presence and absence of $1 \mu \mathrm{M}$ atropine. The reaction was terminated by vacuum filtration through Whatman GF/B filters, followed by three $8 \mathrm{ml}$ rinses with Tris buffer. The filtration and washing took less than $10 \mathrm{sec}$. Bound isotope retained in the filter was extracted into $5 \mathrm{ml}$ of a Triton-toluenephosphor scintillation cocktail and radioactivity monitored in a liquid scintillation spectrometer (Beckman LS-7000) with an efficiency of $45 \%$. Specific binding is expressed as femtomol ligand/mg protein.

Protein assay: Protein determination was by the method of Lowry et al. (14).

Calculation and statistics: Each sample was analyzed in triplicate and the significance of the difference between groups was analyzed using a two-tailed Student's $t$-test. Correlation among the parameters studied were determined by linear regression.

Drugs and radiochemicals: $\left[{ }^{3} \mathrm{H}\right]$ Muscimol (29.4 Ci/mmol), [ $\left.{ }^{3} \mathrm{H}\right]$ QNB $(33.1 \mathrm{Ci} / \mathrm{mmol})$, $\left[{ }^{3} \mathrm{H}\right]$ pirenzepine $(82.3 \mathrm{Ci} / \mathrm{mmol})$ and $\left[{ }^{14} \mathrm{C}\right]-$ acetyl-Coenzyme A $(53.5 \mathrm{mCi} / \mathrm{mmol})$ were purchased from New England Nuclear. $r$ Aminobutyrate aminotransferase, NADP, GABA and acetyl-CoA were from Sigma. $\alpha$-Ketoglutarate, glutamate, pyridoxal phosphate, mercaptoethanol, choline chloride, atropine, physostigmine, acetonitrile, sodium tetraphenylboron and Triton X-100 were from Nakarai.

\section{Results}

Characterization of $\left[{ }^{3} \mathrm{H}\right]$ muscimol binding in the human brain: Prior treatment of membranes with $0.05 \% \mathrm{~V} / \mathrm{V}$ Triton $\mathrm{X}-100 \mathrm{sig}$ nificantly increased the specific binding of $\left[{ }^{3} \mathrm{H}\right]$ muscimol, as previously reported in other mammals (8). Scatchard analysis of the binding data derived from experiments using Triton-treated $\quad\left(K_{d}=12.6 \quad n M, \quad B_{\max }=682\right.$ $\mathrm{fmol} / \mathrm{mg}$ protein) and non-treated membranes $\left(K_{d}=50.3 \mathrm{nM}, B_{\max }=612 \mathrm{fmol} / \mathrm{mg}\right.$ protein) revealed that this increase represents an augmentation in the affinity of the $G_{A B A_{A}}$ receptor rather than a change in the number of binding sites. The supernatant obtained through Triton treatment of the membranes, when added to the assay mixture for $\left[{ }^{3} \mathrm{H}\right]$ muscimol binding, caused reductions of the specific binding to both Triton-treated and nontreated membranes in a concentrationdependent manner (data not shown).

Several GABA agonists and antagonists were tested for their ability to inhibit $\left[{ }^{3} \mathrm{H}\right]$ muscimol binding (Table 2 ). The relative potencies were as follows: muscimol $>3$ aminopropanesulfonate (3-APS) $>$ GABA $>$ (+)bicuculline. Picrotoxin, a GABA antagonist, does not interfere with $\left[{ }^{3} \mathrm{H}\right]$ muscimol binding, reflecting that picrotoxin binds to the chloride ionophore rather than the GABA receptor recognition sites. Nipecotic acid, an inhibitor of neuronal GABA transport, has essentially no affinity for the muscimol site.

To determine whether or not the binding sites for muscimol represent functional GABA receptor coupled to benzodiazepine binding 
sites, effects of diazepam on $\left[{ }^{3} \mathrm{H}\right]$ muscimol binding were examined. In the prefrontal cortex membranes from control subjects. diazepam at $10 \mu \mathrm{M}$ enhanced the specific $\left[{ }^{3} \mathrm{H}\right]$ muscimol binding, as described (15).

$\left[{ }^{3} \mathrm{H}\right]$ Muscimol binding: As shown in Fig. 1 (bottom), the amount of $\left[{ }^{3} \mathrm{H}\right]$ muscimol binding in the control brains was rather

Table 2. Pharmacological profiles of $\left[{ }^{3} \mathrm{H}\right]$ muscimol binding to human brain membranes

\begin{tabular}{lc}
\hline Compound & $K_{i}(n M)$ \\
Muscimol & 4 \\
3-Aminopropanesulfonate (3-APS) & 7 \\
GABA & 8 \\
(+)-Bicuculline & 553 \\
Picrotoxin & $>10,000$ \\
( \pm -Nipecotic acid & $>10,000$ \\
\hline
\end{tabular}

Inhibition of specific $\left[{ }^{3} \mathrm{H}\right]$ muscimol (final concentration: $20 \mathrm{nM}$ ) binding by various concentrations of the different compounds was determined using the standard assay procedure with Triton-treated membrane preparations (cerebral cortex). $K_{i}$ values (inhibition constants) were obtained using the equation: $K_{i}=\mid C 50 /$ $\left(1+L / K_{D}\right)$, in which $1 C 50=$ concentration which inhibits specific $\left[{ }^{3} \mathrm{H}\right.$ ] muscimol binding $50 \%$, $L=$ concentration of labeled ligand and $\mathrm{K}_{\mathrm{D}}=$ dissociation constant of the ligand.
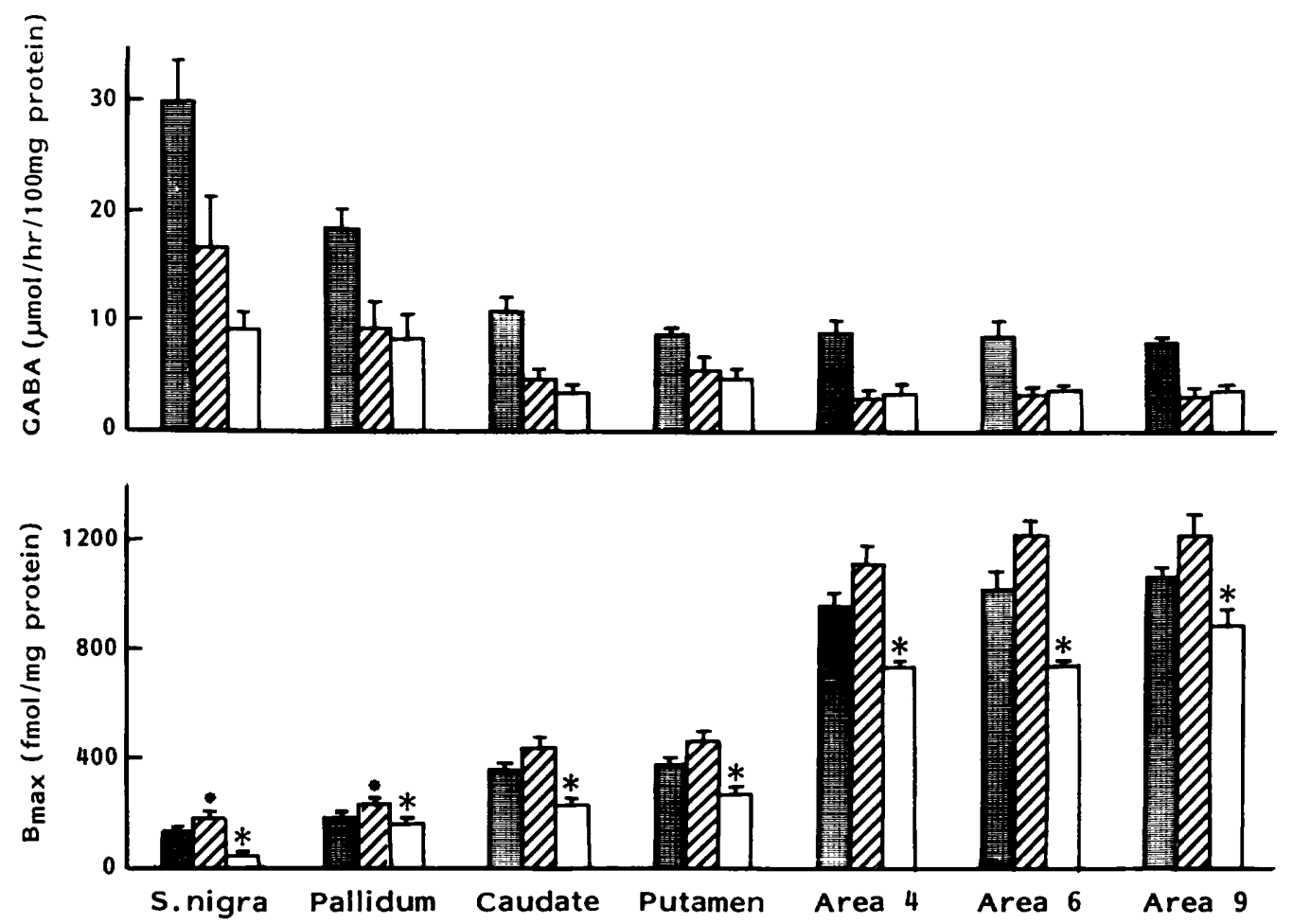

Fig. 1. GAD activity (upper) and $\left[{ }^{3} \mathrm{H}\right]$ muscimol binding (lower) in control and parkinsonian brains. Columns with bar represent the mean \pm S.E. Mode of death of control subjects was considered under two major categories of agonal status: sudden death cases $(n=7$, shaded columns) and prolonged terminal illness $(n=7$, columns with oblique lines). Open columns for the parkinsonians. Final concentration of $\left[{ }^{3} \mathrm{H}\right]$ muscimol was varied between 2.5 and $160 \mathrm{nM} . \quad * P<0.05$ : statistically significant when compared to the mean value for prolonged terminal illness cases. $* P<0.05$ : statistically significant when compared to the mean value for sudden death cases. 
unevenly distributed. The highest binding level was found in the cerebral cortex. The binding to the caudate nucleus and putamen was almost equal, less than half of that found in the cortex, with the pallidum and substantia nigra displaying the least amount of binding at about $20 \%$ of the cortical level. We were unable to determine any significant correlations between the binding and the age. sex and postmortem delay of the control subjects. However, when the control cases were subdivided into two groups on their mode of death, the $B_{\max }$ value for $\left[{ }^{3} \mathrm{H}\right]$ muscimo! bindings was significantly higher in the substantia nigra and pallidum of brains from PTI cases than that of SD cases. There was a tendency in other regions from PTI cases to increase. In PD, the specific bindings of $\left[{ }^{3} \mathrm{H}\right]$ muscimol were decreased in all brain regions studied as compared with the controls. Scatchard analysis revealed that these binding changes were caused by decreased receptor densitiy rather than changes in affinity (data not shown). These reductions were statistically significant regardless of whether mean $B_{\max }$ value from the parkinsonians were compared with the value from SD cases or with the value from PTI cases.

GAD activity: The distribution of GAD in various areas of the control brains was similar to that reported for humans (16). It was also in good agreement with the distribution of GABA-like immunoreactivities in the mouse and rat brain (17). Thus, the substantia nigra showed the highest activity. The value in the pallidum was intermediate and lowest in the striatum and cerebral cortex. In PD brains, there was a tendency for the GAD activity to be reduced with statistical significance in the caudate nucleus and substantia nigra as compared to the controls. However, the GAD activity in the brains of control subjects who
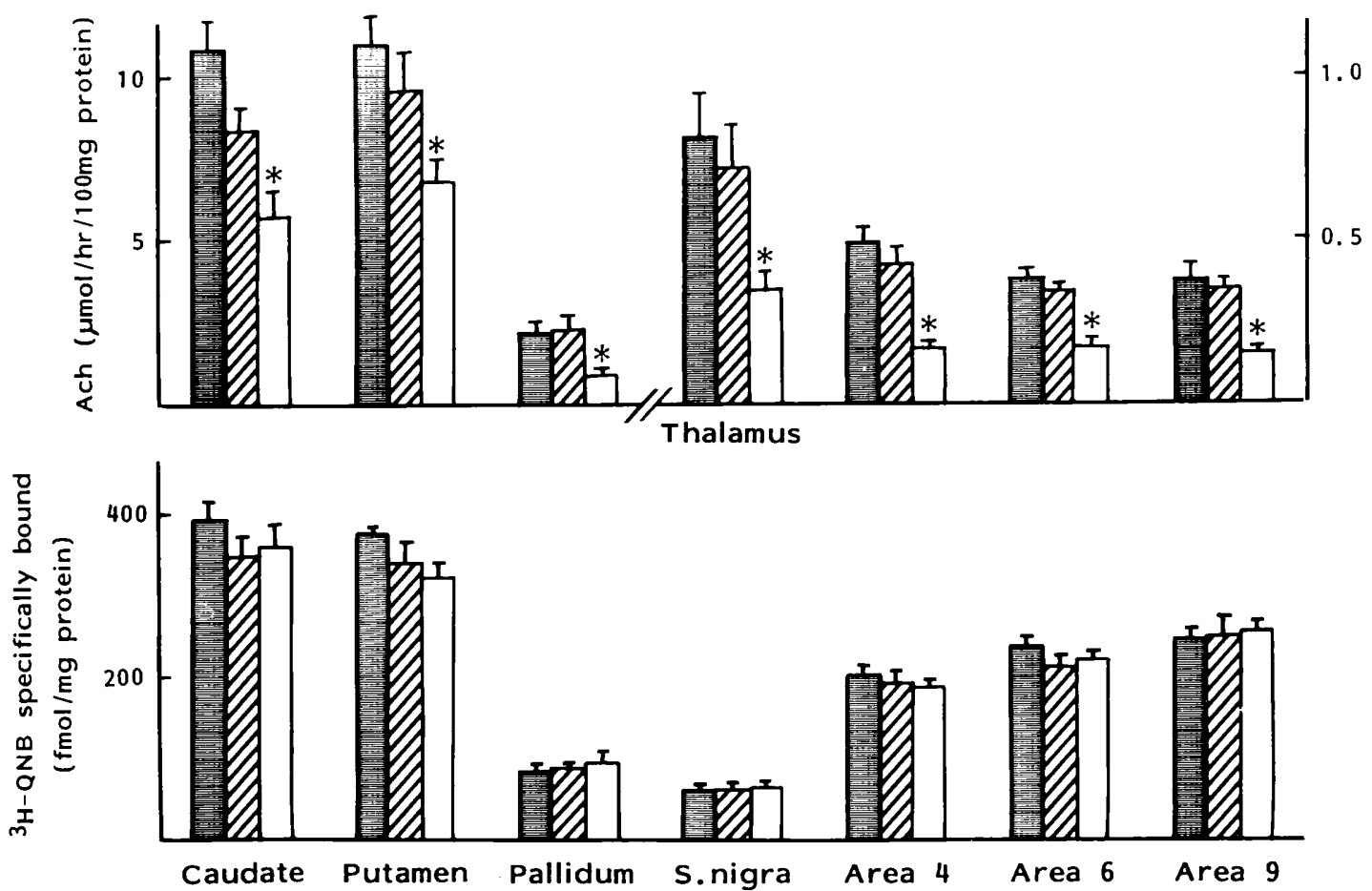

Fig. 2. ChAT activity (upper) and [ $\left.{ }^{3} \mathrm{H}\right] \mathrm{QNB}$ binding (lower) in control and parkinsonian brains. Columns with bar denote the mean \pm S.E.: sudden death cases of controls ( $n=7$, shaded columns), prolonged terminal illness cases of controls $(n=7$, columns with oblique lines) and parkinsonians ( $n=8$, open columns). Fina! concentration of the radioligand used was $1 \mathrm{nM} . * P<0.05$ : statistically significant when compared to the mean value for prolonged terminal illness. 
died following protracted terminal illness (PTI) was reduced in comparison with the values obtained following sudden death (SD). When GAD values for control subjects suffering PTI were compared, no significant differences were found for GAD activity between the controls and parkinsonians (Fig. 1. upper). There was no significant correlation between the GAD activity and the $\left[{ }^{3} \mathrm{H}\right]$ muscimol binding $(\mathrm{P}>0.05)$.

$\left[{ }^{3} \mathrm{H}\right] \mathrm{ONB}$ and $\left[{ }^{3} \mathrm{H}\right]$ pirenzepine binding: In control brains, the striatum had the highest binding capacity for $\left[{ }^{3} \mathrm{H}\right] \mathrm{QNB}$. The values in the cerebral cortices were intermediate and the lowest in the substantia nigra and pallidum. There were not any significant differences between the SD and PTI cases. We were unable to determine any significant correlations between the binding and the sex, aging, agonal state and postmortem delay. In PD brains, the specific $\left[{ }^{3} \mathrm{H}\right] \mathrm{ONB}$ bindings showed no alteration as compared to the values in the SD or PTI cases (Fig. 2, bottom). We found no up-regulation of $\left[{ }^{3} \mathrm{H}\right] \mathrm{ONB}$ binding in any brain region of the PD subjects with dementia $(n=3)$, in which reductions in ChAT activity were noted (data not shown). Scatchard analysis of the specific $\left[{ }^{3} \mathrm{H}\right]$ pirenzepine binding to the putamen revealed no changes in binding constants between the control $\left(K_{d}=3.2 \pm 0.015 n M, B_{\max }=657 \pm\right.$ $24.9 \mathrm{fmol} / \mathrm{mg}$ protein, $n=14$ ) and $P D$ subjects $\left(K_{d}=3.1 \pm 0.022 \quad n M, B_{\max }=658 \pm 43.7\right.$ $\mathrm{fmol} / \mathrm{mg}$ protein, $\mathrm{n}=8$ ).

ChAT activity: The ChAT activity in control brain was unevenly distributed: the values were highest in the striatum, intermediate in the thalamus and lowest in the cerebral cortices and pallidum. They did not differ between the SD and PTI cases. In PD brains, the ChAT activity was significantly reduced in all regions studied as compared to controls (Fig. 2, upper). The reduction in ChAT activity was more prominent in $\mathrm{PD}$ patients with clinically overt dementia (e.g., putamen: $5.4 \pm 0.8 \mu \mathrm{mol} / \mathrm{hr} / 100 \mathrm{mg}$ protein, $\mathrm{n}=3$ ) than in those without dementia $(8.9 \pm 1.2$ $\mu \mathrm{mol} / \mathrm{hr} / 100 \mathrm{mg}$ protein, $\mathrm{n}=5$ ). We were unable to determine any significant correlations between the enzyme activity and the sex, mode of death and postmortem delay, but age-related loss of the activity was observed (e.g., frontal cortex: $r=-0.731$, $P<0.05, n=15)$. There was no significant correlation between ChAT activity and $\left[{ }^{3} \mathrm{H}\right]$ QNB binding ( $P=0.05)$.

\section{Discussion}

Treating the membranes with low concentrations of the detergent Triton X-100 increased the specific $\left[{ }^{3} \mathrm{H}\right]$ muscimol binding, which is not necessarily synonymous with the most physiological state of the receptor protein. The increased binding may result from better removal of endogenous GABA. removal of some other inhibitor of $G_{A B A}$ receptor binding such as GABA-modulin (18) or stabilization of a high-affinity conformation of the receptor protein. Drug competition study for muscimol binding revealed the presence of specific $G_{A B A_{A}}$ receptors in human brain, and potentiating effect of diazepam on muscimol bindings further suggested that they represent the functional GABA/benzodiazepine receptor complex (19).

Reduced GAD activities observed in the PD brain may be a consequence of premortem conditions such as prolonged terminal iliness (PTI) rather than the disorder per se, as pointed out by several investigators $(20,21)$. This could be the case with our patients since they were all in a terminal akinetic state at least one month before death. The GAD reductions that we observed were not related to the dosage or duration of $L$-dopa $(P>$ $0.05)$. Reportedly, GABA concentrations in the PD striatum were generally elevated, especially in the caudal putamen (4). Taken these data together, it is conceivable that although the reduced GAD activity in PD might be indicative of vu!nerability of the enzyme to premortem conditions, there may exist a more profound reduction in turnover rate of GABA, thereby consequenting elevated GABA contents.

Densities of $G A B A_{A}$ receptors as labeled by $\left[{ }^{3} \mathrm{H}\right]$ muscimol were decreased in all $P D$ brain regions studied. whereas they tended to increase or even significantly increased in the brain region of $\mathrm{PTI}$ cases, when compared with the values in SD cases. The level of receptor density seems not dependent upon the amounts of endogenous inhibitors, since 
tritonized membranes are devoid of the inhibitors.

Immunohistochemical and lesion studies identify intrinsic GABA-containing neurons in the cerebral cortex, striatum and pallidum (17, 22), striatonigral and striatopallidal GABAergic pathway (23), and non-dopaminergic (probably GABAergic) neurons in the substantia nigra zona reticulata (SNR) which project to the ventromedial thalamus, nucleus parafascicularis, superior colliculus, formatio reticularis, the tegmental pedunculopontine nucleus and the periaqueductal grey (24). Loss of muscimol binding sites in the nigra may reflect the loss of nigral DA neurons on which they lie, as suggested with [ $\left.{ }^{3} \mathrm{H}\right] \mathrm{GABA}$ binding (6); or it may also reflect the loss of non-dopaminergic neurons in the SNR. There is evidence suggesting that bicucullinesensitive GABA receptors (GABA A $_{A}$ receptors) in the SNR mediate or modulate a tonic activity in the electromyogram, which closely reflects muscular rigidity (25). Thus, decreased $\mathrm{GABA}_{A}$ receptors in the SNR may also play some role in the generation of muscular rigidity in $\mathrm{PD}$.

GABA and related agonists have been shown to modulate DA (26) and ACh (27) release in the striatum via presynaptic $G A_{B A}$ receptors, although several studies have revealed that striatal DA release inhibition by GABA is mediated by bicuculline-insensitive and baclofen-sensitive GABA receptors (GABA $A_{B}$ receptors) $(9,28)$. We failed to identify possible alterations in $\mathrm{GABA}_{B}$ receptors in PD because of an extremely high noise/signal ratio by using $\left[{ }^{3} \mathrm{H}\right]$ baclofen as a ligand (data not shown). If DA release in the human striatum are modulated by presynaptic $G A B A_{A}$ receptors, then the decreased binding of $\left[{ }^{3} \mathrm{H}\right]$ muscimol in the PD striatum should be a change secondary to the degeneration of nigrostriatal DA pathway. Alternatively, if DA is inhibitory on GABAergic striatal output neurons, then the removal of this inhibitory effect should cause the striatal neurons to be hyperactive and result in receptor down-regulation in striatal projection areas (pallidum and substantia nigra in the present study), including the striatum itself in which the local axon collateral terminals of striatonigral GABAergic neurons form syn- aptic contacts with dendrites and axon initial segments of neighboring neurons (22).

Finally, cortical DA, noradrenaline, serotonin and their metabolites have been shown to decrease in PD (29). suggesting that the illness affects these monoaminergic neuronal systems not only in the basal ganglia but also in neocortical and limbic structures. It is likely that cortical intrinsic GABAergic neurons make synaptic contact with some of these ascending monoaminergic neurons and that $\mathrm{GABA}_{\mathrm{A}}$ receptors located at presynaptic terminals of the monoaminergic neurons are lost as secondary consequences of the degenerative process involving corticolimbic structures.

ChAT activity in brains of PD has been measured to yield conflicting results: it is either normal $(1,3)$ or reduced (2). ChAT is not the rate-limiting step in acetylcholine synthesis and apparent loss of enzyme activity may not be directly related to alterations in cholinergic activity. Cholinergic deficit in senile dementia of the Alzheimer type is known to not affect all of the cholinergic system to the same degree: reductions in ChAT activity are most marked in the temporal cortex, hippocampus and amygdala (major projection areas of the nucleus basalis and septal area (30)), whereas within the basal forebrain, it was confined to the area of the nucleus basalis and was not apparent in the adjacent putamen and pallidum (31). In the present study, the activity was significantly reduced in both cortical and subcortical brain regions of PD with marked reduction in the demented cases. With this respect, our results may support a contention of subcortical dementia in PD.

Albeit marked reductions in ChAT activity, muscarinic receptors as labeled by $\left[{ }^{3} \mathrm{H}\right]$ QNB were normal in the brains of PD. Multiplicity of muscarinic receptor $\left(M_{1}\right.$ and $\mathrm{M}_{2}$ ) has been demonstrated in laboratory anima!s and in humans $(10,32,33)$. These evidence prompted us to examine $M_{1}$ receptors in PD striatum, in which $M_{1}$ receptors regulating striatal DA release are supposed to be lost as a consequence of the loss of DA terminals. However, there were no changes in receptor indices of the specific $\left[{ }^{3} \mathrm{H}\right]$ pirenzepine binding in PD putamen, where 
the loss of DA contents is most prominent. It remains to be explained why pirenzepine binding sites were normal in PD. One explanation may be that in the PD striatum, upregulation of $M_{1}$ receptors, which might have developed on unidentified neurons (possibly GABA or substance-P containing neurons) target to intrinsic $A C h$ containing neurons, cancels loss of $M_{1}$ receptors which may localize on dopaminergic terminals.

We speculate that GABA/DA imbalance as well as ACh/DA imbalance are involved in the pathophysiology of human parkinsonism. at least in the terminal akinetic state of PD.

Acknowledgments: This work was supported by a Grant-in-Aid for Special Project Research of Selected Intractable Neurological Disorders from the Ministry of Education, Science and Culture, Japan. We thank Prof. Y. Mizoi, Department of Legal Medicine, Prof.

T. Sugiyama, Department of Pathology and Prof. T. Yamadori, Department of Anatomy, Kobe University School of Medicine for the brain specimens.

\section{References}

1 Gaspar, P., Javoy-Agid, F., Ploska, A. and Agid, Y.: Regional distribution of neurotransmitter synthesizing enzymes in the basal ganglia of human brain. J. Neurochem. 34, 278-283 (1980)

2 Lloyd, K.G., Mohler, H., Heitz, P.H. and Bartholini, G.: Distribution of choline acetyltransferase and glutamate decarboxylase within the substantia nigra and in other brain regions from control and parkinsonian patients. J. Neurochem. 25, 789-795 (1975)

3 McGeer, P.L., McGeer, E.G. and Wada, J.A.: Glutamic acid decarboxylase in Parkinson's disease and epilepsy. Neurology 21, 1000-1007 (1971)

4 Kish, S.J., Rajput, A., Gilbert, J., Rozdilsky, B., Chang, L.J., Shannak, K. and Hornykiewicz, O.: Elevated $\gamma$-aminobutyric acid level in striatal but not extrastriatal brain regions in Parkinson's disease: correlation with striatal dopamine loss. Ann. Neurol. 20, 26-31 (1986)

5 Lloyd, K.G., Shemen, L. and Hornykiewicz, O.: Distribution of high affinity sodium-independent $\left[{ }^{3} \mathrm{H}\right]$ gamma-aminobutyric acid ([3 $\left.\left.\mathrm{H}\right] \mathrm{GABA}\right)$ binding in the human brain: alterations in Parkinson's disease. Brain Res. 127, 269-278 (1977)

6 Rinne, U.K., Koskinen, V., Laaksonen, H., Lonnberg, P. and Sonninen, V.: GABA receptor binding in the parkinsonian brain. Life Sci. 22,
$2225-2228$ (1978)

7 Dubois, B., Ruberg, M., Javoy-Agid, F., Ploska, A. and Agid, Y.: A subcortico-cortical cholinergic system is affected in Parkinson's disease. Brain Res. 288, 213-218 (1983)

8 Beaumont, K., Chilton, W.S., Yamamura, H.I. and Enna, S.J.: Muscimol binding in rat brain: association with synaptic GABA receptors. Brain Res. 148, 153-162 (1978)

9 Bowery, N.G., Hill, D.R. and Hudson, A.L.: Characteristics of $G A B A_{B}$ receptor binding sites on rat whole brain synaptic membranes. Br. J. Pharmacol. 78, 191-206 (1983)

10 Hammer, R., Berrie, C.P., Birdsall, N.J.M., Burgen, A.S.V. and Hulme, E.C.: Pirenzepine distinguishes between different subclasses of muscarinic receptors. Nature 283, 90-92 (1980)

11 Hoehn, M.M. and Yahr, M.D.: Parkinsonism: onset, progression and mortality. Neurology 17, 427-442 (1967)

12 Okada, Y., Taniguchi, H. and Shimada, C.: High concentration of GABA and high glutamate decarboxylase activity in rat pancreatic islets and human insulinoma. Science 194, 620-622 (1976)

13 Fonnum, F.: A rapid radiochemical method for the determination of choline acetyltransferase. J. Neurochem. 24, 407-409 (1975)

14 Lowry, O.H., Rosebrough, M.J., Farr, A.L. and Randall, R.J.: Protein measurement with the Folin phenol reagent. J. Biol. Chem. 193, 421428 (1951)

15 Hanada, S., Mita, T., Nishino, N. and Tanaka, C.: $\left[{ }^{3} \mathrm{H}\right]$ Muscimol binding sites increased in autopsied brains of chronic schizophrenics. Life Sci. 40, 259-266 (1987)

16 Mackay, A.V.P., Davies, P., Dewar, A.J. and Yates, C.M.: Regional distribution of enzymes associated with neurotransmission by monoamines, acetylcholine and GABA in the human brain. J. Neurochem. 30, 827-839 (1978)

17 Ottersen, O.P. and Storm-Mathisen, J.: Glutamate- and GABA-containing neurons in the mouse and rat brain, as demonstrated with a new immunocytochemical technique. I. Comp. Neurol. 229, 374-392 (1984)

18 Guidotti, A., Konkel, D.R., Ebstein, B., Corda, M.G., Wise, B.C., Krutzsch, H., Meek, J.L. and Costa, E.: Isolation, characterization, and purification to homogeneity of a rat brain protein (GABA-modulin). Proc. Natl. Acad. Sci. U.S.A. 79, 6084-6088 (1982)

19 Schofield, P.R., Darlison, M.G., Fujita, N., Burt, D.R., Stephenson, F.A., Rodriguez, H., Rhee, L.M., Ramachandran, J., Reale, V., Glencorse, 
T.A., Seeburg, P.H. and Barnard, E.A.: Sequence and functional expression of the GABAA receptor shows a ligand-gated receptor super-family. Nature 328, 221-227 (1987)

20 Monfort, J.C., Javoy-Agid, F., Hauw, J.J., Dubois, B. and Agid, Y.: Brain glutamate decarboxylase in Parkinson's disease with particular reference to a premortem severity index. Brain 108, 301-313 (1985)

21 Spokes, E.G.: An analysis of factors influencing measurements of dopamine, noradrenaline, glutamate decarboxylase and choline acetylase in human post-mortem brain tissue. Brain 102 , 333--346 (1979)

22 Ribak, C.E., Vaughn, J.E. and Roberts, E.: The GABA neurons and their axon terminals in rat corpus striatum as demonstrated by GAD immunocytochemistry. J. Comp. Neurol. 187, 261-284 (1979)

23 Johnson, T.N. and Rosvold, H.E.: Topographic projections on the globus pallidus and the substantia nigra of selectively placed lesions in the precommissural caudate nucleus and putamen in the monkey. Exp. Neurol. 33, 584596 (1971)

24 Scheel-Kruger, J., Magelund, G. and Olianas, M.C.: Role of GABA in the striatal output system: globus pallidus, nucleus entopeduncularis, substantia nigra and nucleus subthalamicus. In GABA and the Basal Ganglia, Edited by Di Chiara, G. and Gessa, G.L., p. 165-186, Raven Press, New York (1981)

25 Havemann, U., Turski, L., Schwarz, M. and Kuschinsky, K.: Nigral GABAergic mechanisms and EMG activity in rats: differences between pars reticulata and pars compacta. Eur. J. Pharmacol. 92, 49-56 (1983)

26 Bartholini, G. and Stadler, H.: Evidence for an intrastriatal GABA-ergic influence on dopamine neurones of the cat. Neuropharmacology 16, 343-347 (1977)

27 Supavilai, P. and Karobath, M.: Modulation of acetylcholine release from rat striatal slices by the GABA/benzodiazepine receptor complex. Life Sci. 36, 417-426 (1985)

28 Reiman, W., Zumstein, A. and Starke, K.: $\gamma$ Aminobutyric acid can both inhibit and facilitate dopamine release in the caudate nucleus of the rabbit. J. Neurochem. 39, 961-969 (1982)

29 Scatton, B., Javoy-Agid, F., Rouquier, L., Dubois, B. and Agid, Y.: Reduction of cortical dopamine, noradrenaline, serotonin and their metabolites in Parkinson's disease. Brain Res. 275, 321-328 (1983)

30 Mesulam, M.M., Mufson, E.J., Levy, A.I. and Wainer, B.H.: Cholinergic innervation of cortex by the basal forebrain: cytochemistry and cortical connections of the septal area, diagonal band nuclei, nucleus basalis (substantia innominata). and hypothalamus in the rhesus monkey. J. Comp. Neurol. 214, 170-197 (1983)

31 Rossor, M.N., Svendsen, C., Hunt, S.P., Mountjoy, C.Q., Roth, M. and Iversen, L.L.: The substantia innominata in Alzheimer's disease: an histochemical and biochemical study of cholinergic marker enzymes. Neurosci. Lett. 28, 217-. 222 (1982)

32 Garvey, J.M., Rossor, M. and Iversen, L.L.: Evidence for multiple muscarinic receptor subtypes in human brain. J. Neurochem. 43, 299-302 (1984)

33 Raiteri, M., Leardi, R. and Marchi, M.: Heterogeneity of presynaptic muscarinic receptors regulating neurotransmitter release in the rat brain. J. Pharmacol. Exp. Ther. 228, 209-228 (1984) 